\title{
A nemi dysphoria jogi vonatkozásai és a kezelés folyamata Magyarországon
}

\author{
Kórász Krisztián dr. \\ Oxleas NHS Foundation Trust, London, Egyesült Királyság
}

\begin{abstract}
Magyarországon a múltban a nemváltoztatás jogi eljárása a legtöbb európai országhoz képest fejlettnek számított, a jog ugyanis lehetővé tette a transzszexuális személyek számára az orvosi kezelést megelóző́en vagy a nélkül is a névés nemváltoztatást, amely eljárás akkoriban egyedinek volt tekinthető. Az évek során több európai ország is a nemi dysphoria kezelését segító jogi keretet biztosított és nemzetközi szabványokat fogadott el, amely gyakorlatot Magyarország nem követett. Jelenleg Magyarországon a nemváltoztatásnak nincs összefüggő jogi kerete, nincs hivatalos szabályozása, illetve a kezelésnek irányelve. A kezelés elvégzéséhez nincs intézet rendelve, valamint az állami egészségügyben nincs kinevezett szakember, akinek a megbízása kiterjedne a transzszexuális betegek ellátására. A nemváltoztatás lehetőségeinek információja mind a szakemberek, mind a betegek számára korlátozott és töredezett. A közlemény áttekinti a nemi dysphoria magyarországi jogi vonatkozásait és a kezelés folyamatát. A magyar gyakorlattal kapcsolatos egyes problémák és azok lehetséges megoldásai az Egyesült Királyság példáján keresztül kerül bemutatásra. Orv. Hetil., 2015, 156(30), 1214-1220.
\end{abstract}

Kulcsszavak: nemi dysphoria, transzszexualizmus, nemi identitás zavara, nemi átalakító mútét, nemváltoztatás

\section{Legal aspects and the treatment procedure of gender dysphoria in Hungary}

The legal process of gender transition in Hungary had previously been more developed as in most European countries, as the law enabled transsexual people to change their name and gender before or without a medical treatment, which was unique at the time. Over the years, however, lots of European countries developed legal frameworks and accepted international standards of care for the treatment of gender dysphoria that Hungary did not follow. Currently in Hungary there is no consistent legal framework of gender transition, there is no official regulation or guidelines regarding gender transition process, no institution with the obligation to accommodate the process, and there is no nominated specialist in the state health care system whose remit included dealing with transsexual patients. The information on gender transition options both to the professionals and to the patients is limited and incoherent. This paper reviews the legal aspects and clinical management process of gender dysphoria in Hungary. Some issues regarding the Hungarian practice and possible solutions based on examples from the United Kingdom are addressed within the paper.

Keywords: gender dysphoria, transsexualism, gender identity disorder, sex reassignment surgery, gender transition

Kórász, K. [Legal aspects and the treatment procedure of gender dysphoria in Hungary]. Orv. Hetil., 2015, 156(30), 1214-1220.

(Beérkezett: 2015. május 13.; elfogadva: 2015. június 11.)

\section{Rövidítések}

BNO-10 = Betegségek nemzetközi osztályozása, tizedik kiadás; DSM-V = (Diagnostic and Statistical Manual of Mental Disorders) az Amerikai Pszichiátriai Társaság ötödik kiadású diagnosztikai kézikönyve; ETT = Egészségügyi Tudományos Tanács; FTM = (female-to-male) férfiidentitású, genetikailag nő transzszexuális; GRC = (Gender Recognition Certificate $)$
Nemi Elismerő Igazolás; KIM = Közigazgatási és Igazságügyi Minisztérium; MTF = (male-to-female) női identitású, genetikailag férfi transzszexuális; RLT vagy $\mathrm{RLE}=($ Real Life Test vagy Real Life Experience) Valódi Élet Teszt vagy Valódi Élet Tapasztalat; SRS vagy GRS = (Sex Reassignment Surgery vagy Gender Reassignment Surgery) nemi átalakító mútét; WPATH $=$ World Professional Association for Transgender Health 
Az Egészségügyi Világszervezet 1980-ban adta ki a BNO-10-et (BNO-10 = Betegségek nemzetközi osztályozása, tizedik kiadás), amiben a transzszexualitást betegségnek nyilvánították. A BNO-10 a nemi identitás zavarai csoportba sorolja a transzszexualizmust. A betegség diagnosztikus kritériumait alkotja a vágyakozás az iránt, hogy az egyén ellenkező nemü egyénként élhessen és fogadják el. A beteg általában a saját nemével és anatómiájával elégedetlen, kényelmetlenül érzi magát benne, valamint sebészi és hormonkezeléseket szeretne, hogy testét, amennyire csak lehet, a kívánt nemhez tegye hasonlatossá. A transzszexuális identitásnak legalább két éve fenn kell állnia, és más mentális zavar tüneteinek, mint amilyen a szkizofrénia, nem szabad jelen lennie, illetve a zavar sem genetikai, sem kromoszomális, sem pedig interszexuális abnormalitásokhoz nem társulhat [1].

A transzszexuális személyek némelyike, különösen azok, akik az élet egyéb területén kitünően funkcionáltak, kifogásolták, hogy problémájukat pszichiátriai zavarként azonosítják. A transzszexuális közösség aktivistái alternatív megfogalmazást javasoltak, hogy ezzel is elejét vegyék a megbélyegzésnek. A transzszexualizmus inkább szomatikus, mintsem pszichiátriai betegségnek minősítése által szerették volna elkerülni a stigmatizációt, de egyben konzerválták volna az egészségbiztosítók által finanszírozott nemi átalakító mütétek (SRS vagy GRS = Sex Reassignment Surgery vagy Gender Reassignment Surgery) lehetőségét. E probléma megoldását jelentheti a DSM-V-ben (Diagnostic and Statistical Manual of Mental Disorders - az Amerikai Pszichiátriai Társaság ötödik kiadású diagnosztikai kézikönyve) meghozott változtatás, ahol a nemi identitás zavarát a nemi dysphoria terminológiával cserélték fel. A nemi dysphoria úgy határozható meg, mint a biológiai nemmel szembeni elégedetlenség, az ellenkező nem testének birtoklása iránti vágy, és annak az óhaja, hogy az egyént ellenkező nemúként fogadja el a környezete, a társadalom [2].

A nemi dysphoria gyógyításának elismert formája a nemváltoztatás, amely összetett jogi, etikai és legfőképpen igen magas szinten koordinált speciális szakmai ismereteket követelő eljárás. A kezelés által a személy fizikai és pszichológiai nemisége összhangba kerül, ami által önelfogadása növekszik. Megjegyzendő, hogy a transzszexuális egyének csak egy része kívánja a külső nemi jellegének megváltoztatását. A betegek egy része mütét és hormonális kezelés nélkül él a kívánt énje szerint, valamint némely személy számára a hormonális és pszichológiai segítség mütéti beavatkozás nélkül is elegendő.

\section{Jogi előzmények}

A múltban a személyazonossági papírok módosításának illetékességek általi elutasítása esetén fennállt annak a veszélye, hogy a transzszexuálisoknak kötelezően számtalan ember előtt fel kellett fedniük külső megjelenésük és polgári státusuk eltérésének okát, valamint a speciális előírások hiányában a transzszexuális személyek gya- korta diszkrimináció és erőszak áldozataivá váltak magánéletükben. Ezen okok miatt az Európa Tanács Parlamenti Közgyúlése 1989-ben ajánlást tett a tagoknak - 41. ülésszak, 1117-es (1989) számú ajánlás a transzszexuálisok helyzetéról -, amellyel rendezni kívánta a transzszexuálisok helyzetét. Az Európa Tanács javasolta az érintett személy nemének módosítását a születési anyakönyvben, valamint a személyi igazolványban, az utónév-változtatások engedélyezését, a személy magánéletének védelmét, az alapvető jogok és szabadságjogok élvezésében való minden diszkrimináció megtiltását.

Az első SRS iránti igény Magyarországon az 1990-es évek végén jelentkezett, azonban a magyar jogalkotás a 2000-es évek elején kezdett el foglalkozni a transzszexualitás orvosszakmai és jogi szabályozásával. Ennek során figyelembe vették a transzszexuálisok helyzetéről szóló Európa Tanács-ajánlást, a jogszabályok külföldi gyakorlatát, valamint az országban akkor a legtöbb, nemátalakító mütétet végző plasztikai sebész állásfoglalását. A jogalkotók munkáját az Egészségügyi Tudományos Tanács (ETT) is segítette. Ez idő alatt a következő külföldi példák álltak a jogalkotók előtt: A németországi jogszabályok akkor engedélyezték a transzszexuális személy névváltoztatását, ha a kérelmező legalább három éve a transzszexuális meggyőződése szerint élt; legalább huszonöt éves volt; nem volt házas; tartósan szaporodásképtelen volt; olyan nemi jelleget megváltoztató beavatkozáson volt túl, amelynek eredményeként sikeresen közelítette az ellenkező nem külsőségeit. Ausztriában ez idő alatt az illetékes egyeztető tárcák arra az egységes álláspontra helyezkedtek, hogy a nyilvánvalóan csekély számú eset miatt nem célszerű a nemi átalakulással kapcsolatos jogszabályalkotás kezdeményezése. Azokat az eseteket külön kezelték és bírálták el, amelyekben a kérelmezőn már operatív és azt kísérő egyéb orvosi eljárásokat végeztek annak érdekében, hogy legalább külső megjelenésében az ellenkező nemúhöz tegyék hasonlóvá. Ilyen esetekben a tényálláshoz igazították a jogállást, amelyet széljegyzetben szerepeltettek az anyakönyvben. Franciaországban, a többi nyugateurópai országhoz képest, a nemi hovatartozás jogi megváltoztatása viszonylag szigorú, eseti jog alapján történt. Olaszországban a nemi hovatartozás jogi megváltoztatása viszonylag egyszerűnek volt mondható. Az eljárás szükséges feltétele volt, hogy a kérelmező betöltse a 18 . életévét, hogy amennyiben nem patológiás hormonhatásra vagy egyéb, a kérelmezőtől független okból kifolyólag következett be a változás, úgy a másodlagos nemi jellegét, a külső nemi szerveket módosító mütétnek vesse alá magát. A mútéthez bírósági hozzájárulás, a jogi eljáráshoz kötelezően ügyész részvétele szükségeltetett.

A nemzetközi irodalom szerint a felnőtt transzszexuálisok túlnyomó többsége gyerekkori szexuális identitászavarban szenvedett, vagyis a gyermekkorban jelentkező ellentétes nemi identitás egyértelmúen kockázati tényezője a felnőttkori ellentétes nemi identitásérzésnek. 
A gyerekkori nemi identitászavarban szenvedő fiúk gyakori lányos viselkedése azonban csökken serdülőkorban. A gyerekkori nemi dysphoria felnőttkorban a transzszexualizmustól eltéró kimenetelú is lehet. A kora 60-as évek kutatási eredményei az irányba mutattak, hogy a hangsúlyosan nemi atípusos gyerekekre sem jellemző általánosságban, hogy felnőttkorukra transzszexuálisokká válnának. Ezeket a kutatási eredményeket vették figyelembe az európai és egyesült államokbeli jogalkotók, amikor a nemi átalakítás megkezdésének alsó korhatárát 18-21 évben korlátozták $[3,4]$.

Magyarországon a név- és nemváltoztatás, ahogyan a jog az eljárást nevezi, nem egységes jogi keret, konkrét törvényi szabályozás által lett biztosítva, hanem a folyamat törvényi hátterét részenként és elemenként törvények, végrehajtási rendeletek és alkotmánybírósági határozatok szabályozzák. A magyarországi eljárásrend egyedi, és előrelépésnek számított a nemzetközi gyakorlatban, mert a mútéti és hormonkezeléseket megelőzte a névváltoztatás, amely ily módon gyorsan és hatékonyan segítette a betegek társadalmi-közösségi beilleszkedését. A mútéttel ellentétben az adminisztratív eljárás adott esetben visszafordítható.

\section{A nem- és névváltoztatás jogi háttere és annak gyakorlata Magyarországon}

Egy ideig egy központi testület döntött a nemátalakító kezelésekről, és a hivatalos okiratokban a nemváltoztatásra csak a visszafordíthatatlan sebészi beavatkozás után kerülhetett sor. A fentebb részletezett jogalkotási előzmények után a törvényhozás megszüntette a nem- és névváltoztatás feltételéül addig kötelezően előírt mútéti beavatkozás kényszerét. Jelenleg semmilyen orvosi beavatkozás, illetve mútét nem feltétele a nem- és névváltoztatás engedélyeztetésének. A nem- és névváltoztatás törvényi hátterét az 1997. évi CLIV. törvény az egészségügyről, illetve a születési név megváltoztatását illetően a 2010. évi I. törvény az anyakönyvi eljárásról biztosítja. A név- és nemváltoztatás hivatalos gyakorlatát nagyban segítette a 43/2005. (XI. 14.) AB határozat, amely a transzszexuális személyek nemváltoztatását az önrendelkezési jogból vezette le, illetve az 58/2001. (XII. 7.) AB határozat, amelyben az Alkotmánybíróság a transzszexuális személyek névválasztási és névviselési jogát alkotmányos alapjogként ismerte el. A névjog az Alkotmány 54 . $\$$-ának (1) bekezdésében foglalt emberi méltóságból levezethetô alapvetố jog. Minden embernek elidegeníthetetlen joga van az (ön)azonosságát kifejező saját névhez és annak viseléséhez. Ez a jog az állam által nem korlátozható. Az Európai Bíróság kimondta, hogy a névváltoztatáshoz való jog a transzszexuálisok esetében elvezethet odáig, hogy követelhessék az anyakönyvben feltüntetett nevük megváltoztatását, s őket át is kell anyakönyvezni, éspedig nemcsak a nemük, de a nevük változása miatt is. A névjog egyéb elemei - így különösen a névválasztás, a névváltoztatás, a név- módosítás - a jogalkotó által alkotmányosan korlátozhatók. A 2010. évi I. törvény az anyakönyvi eljárásról 69/B. $\$(4)$ bekezdése kimondja: „A nem megváltozásának anyakönyvbe való bejegyzését meg kell tagadni, ha az érintett személy házassága vagy bejegyzett élettársi kapcsolata fennáll." A név- és nemváltoztatáshoz minisztériumi engedély szükséges. Magyar állampolgár születési családi és utónevének megváltoztatását az anyakönyvi ügyekért felelős minisztérium engedélyezheti, ez jelenleg a Közigazgatási és Igazságügyi Minisztérium (KIM) Anyakönyvi Osztálya.

A nem- és névváltoztatási kérelem benyújtásához a minisztérium régebben igazságügyi szakértôi minősítéssel rendelkező két pszichiáter egymástól független és egybehangzó transzszexuális diagnózisát igényelte, valamint azt is megkövetelte, hogy a szakvélemények igazságügyi pszichológusi szakvéleménnyel is alá legyenek támasztva. Ez a gyakorlati szigor azonban enyhült. Jelenleg a név- és nemváltoztatást igénylőnek egy klinikai szakpszichológusi, egy pszichiáteri és MTF (male-tofemale - nói identitású, genetikailag férfi transzszexuális) esetben egy általános urológiai vagy FTM (female-tomale - férfiidentitású, genetikailag nő transzszexuális) esetben nőgyógyászati szakvélemény beszerzése szükséges. A pszichológusnak klinikai pszichológus szakvizsgával kell rendelkeznie, de sem a pszichológusnak, sem a pszichiáternek nem kötelező az igazságügyi képesítés a véleményezéshez. A szakvéleményt kiállítónak szerepelnie kell az Egészségügyi Nyilvántartási és Képzési Központ nyilvántartásában. A pszichiátriai szakvéleménynek tartalmaznia kell egyértelmúen a BNO-10 kóddal együtt (F64.00) a Transzszexualizmus diagnózist, valamint a név- és nemváltoztatással kapcsolatos javaslatot. Az általános urológiai vagy nőgyógyászati szakvélemény célja, hogy az urogenitális apparátus funkcionális és alaki normalitását igazolja, vagyis a szakvéleményben szerepelnie kell, hogy az SRS-nek nincs orvosszakmai szempontból ellenjavallata.

A nem- és névváltoztatás folyamatának elindítását a transzszexuális személy kezdeményezi kérelem formájában, amelyet a KIM Anyakönyvi Osztályára nyújt be. A kérelemben szerepelnie kell az illető jelenlegi adatainak, valamint maximum két, az illető új nemének megfelelő választott utónevének. A nem- és névváltoztatás kérelmében nincs lehetőség a családi név megváltoztatására. A vezetéknév megváltoztatását a bejelentett lakcím szerinti anyakönyvi hivatalban, a nem- és névváltoztatástól teljesen független eljárásban lehet kérni. A nem- és névváltoztatást kérelmezőnek a kérelméhez mellékelnie kell a három darab eredeti szakvéleményt. Egy darab, családi állapotról való nyilatkozatot, amennyiben az illető családi állapota nôtlen, illetve hajadon. Amennyiben a személy elvált, úgy olyan (záradékolt) házassági anyakönyvi kivonat is kell, amelybe a házasság megszűnését bejegyezték. Amennyiben az illető özvegy, úgy a másik házasfél halotti anyakönyvi kivonatát és a házassági anyakönyvi kivonatot is mellékelni kell. A kérvényezőnek csa- 
tolnia kell az eredeti születési anyakönyvi kivonatát is, vagy ha ez nincs meg, akkor ennek tényét a kérelemben fel kell tüntetnie. Az eljárás illetékköteles, amelyet a kérelmezőnek illetékbélyeg formájában kell lerónia, az illetékbélyeget a kérelemre kell ragasztani. Az elbírálási idő általában 1-3 hónap. Pozitív elbírálás esetén a Nemzeti Erőforrás Minisztérium jóváhagyja a szakvéleményeket, a KIM pedig értesíti az illető születés helye szerinti anyakönyvvezetőt. Az anyakönyvvezető az Utólagos megjegyzések rovatba bevezeti, hogy az illető személy neme, neve megváltozott. A KIM ezzel egy időben tájékoztatja a központi adatnyilvántartót a személyi adatokban bekövetkezett változásokról, valamint értesíti a kérelmezőt, hogy a kérelme pozitív elbírálásban részesült. Az érintett személynek ezek után fel kell vennie a születés helye szerinti illetékes polgármesteri hivatal anyakönyvvezetőjével a kapcsolatot, hogy az új anyakönyvét személyesen átvehesse. Mivel az új anyakönyvben a nemés névváltozás tényére nincs utalás, ezért célszerü az anyakönyv átvételekor egy úgynevezett hatósági bizonyítvány kiállítását kérni a helyi anyakönyvvezetőtől, amelyről a 2004. évi CXL. törvény 83. \$ rendelkezik. A hatósági bizonyítvány a nem- és névváltás tényét tanúsítja, benne a korábbi és az új névvel. A bizonyítvány igénylésekor annak célját meg kell nevezni, például „személyazonosság igazolása” vagy „hivatalos ügyek intézése". Az új anyakönyvi kivonat ingyenes, azonban a hatósági bizonyítvány kiállítása illetékköteles, amelyet a kérelmezőnek illetékbélyeg formájában kell lerónia. A bizonyítvány elvesztése esetén egy hasonló dokumentum az anyakönyvvezetőtől bármikor igényelhető, amelyről az 1990. évi XCIII. törvény XXI. melléklete rendelkezik. A KIM engedélyének megérkezésétől számított hatvan napon belül az érintett személynek ki kell cserélnie minden iratát (személyi igazolvány, lakcímkártya, taj-kártya, adókártya, jogosítvány). Ezen okmányok cseréje díjtalan. Az iskolai és nyelvvizsga-bizonyítványok cseréjére a 11/1994. (VI. 8.) MKM rendelet 4. számú mellékletének $11 / \mathrm{b}$ pontja vonatkozik, tehát az érettségi, nyelvvizsga- és OKJ-bizonyítványok cseréjét a kiállító intézmény vagy annak jogutódja végzi. Az eljárásért külön díjat kell fizetni. Felsőoktatási intézményben megszerzett diplomát az adott intézmény nem köteles kicserélni, a megváltozott nevet átvezetik az eredeti diplomára.

A nem hivatalos megváltoztatását követően az érintett a jog szerint minden tekintetben az új nemmel bíró személynek minősül. Az illető az új neme szerint köthet házasságot vagy bejegyzett élettársi kapcsolatot, az új neme szerinti nyugdíjkorhatár vonatkozik rá stb.

\section{A kezelési folyamat nemzetközi és magyarországi gyakorlata}

Az átalakító mưtét javallatának felállítása igen nagy felelősséggel jár, ezért több országban bizottságokat hoztak létre e döntések meghozatalához. Az első ilyen bizottsá- got 1966-ban Baltimore-ban a Johns Hopkins Kórházban alakították ki, amelynek tagjai az operatőr, a pszichiáter, a pszichológus, az endokrinológus, a genetikus és a szociális gondozó volt. Létrejött a Harry Benjamin International Gender Dysphoria Association, amely a későbbiekben a World Professional Association for Transgender Health (WPATH) nevet vette fel, amely megfogalmazta, és azóta több kiadásban továbbfejlesztette iránymutatását. Ezen iránymutatást számos nemzetközi szakmai szervezet követi. A fejlett országok többségében az előzetesen engedélyezett, az egyes betegre vonatkozó, a szakmai protokollok alapján javasolt, de a beteg egyéni testi és lelki adottságait, korát figyelembe vevő kezelési tervet páciensenként egy, azért felelős szakember koordinálja, hozza összhangba az egyes szakmák között. A koordinátor átfogó ismeretekkel és gyakorlattal rendelkezik. Gyakran a szakértők munkáját kezdetben a pszichiáter és a pszichológus koordinálja, majd a mütét megkezdését követően a plasztikai sebész lesz a koordinátor. A befejezett nemi átalakító mútétek után a beteg szabadon dönt arról, hogy a kiegészítő kezeléseket, azaz a hormonkezelést és a pszichoterápiás kezeléseket ki koordinálja. A WPATH iránymutatását követő országokban a gyakorlott és jól felkészült szakemberek - szociális munkás, pszichológus, pszichiáter, endokrinológus, urológus, nőgyógyász, sebész és más szakorvosok - egy központban, csapatot alkotva múködnek. A szociális munkás feladata, hogy az érintett személyt a nemváltoztatás folyamatáról részletes információkkal lássa el. A transzszexuális személy pszichiátriai vizsgálata elsősorban az egyéb állapotok kizárására irányul, mint amilyen a szkizofrénia, egyéb pszichotikus állapotok, a transzvesztitizmus és a nem bináris nemiidentitás-változatok. A nemi átalakítás során folyamatos pszichoterápiás kezelésnek kell folynia egyénileg, személyre adaptálva és felépítve. A mútéti sorozatok idején és után, az új szexuális szerep gyakorlása során a betegre számos lelkileg megterhelő időszak, próbatétel vár, amely során ebben járatos pszichiáter szakember támogatása elengedhetetlen. A nemátalakítás eredménye nemcsak sebészi anatómiai eredmények függvénye, hanem szocializációs és tanulási lehetőségektől is függ, amely utóbbinak a fejlesztését a pszichiáter elősegítheti [5]. A transzszexualizmus kórisme felállításához szükséges nőgyógyász vagy urológus, andrológus szakorvos bevonása is, aki vizsgálatával azt állapítja meg, hogy anatómiai és fiziológiai szempontból a vizsgálatba bevont személy melyik nemhez tartozik, tehát vizsgálatával anatómiai és lehetőség szerint élettani rendellenességeket is kizár. Ritka, de igen lényeges az interszexualitás felnőttkorig nem felismert eseteinek kiszürése, mert ezek kezelése számos alapelvben különbözik a transzszexualitástól. Az interszexualitás kiszűrésére több országban elfogadott gyakorlat a genetikai vizsgálat. Az endokrinológiai vizsgálattal a morbiditás és mortalitás csökkenthető. Az endokrinológiai vizsgálat a hormonterápia beállításához is szükséges, mert nem mindegy, hogy milyen 
hormonszintet és hormonhatást próbálunk antagonizálni az ellenkező nem hormonjaival. A hormonterápia megkezdése elótti alapvizsgálatokhoz tartozik a trombózishajlam-vizsgálat, egy nagylabor, hasi ultrahang, mellultrahang és hormonszúrés (tesztoszteron, ösztrogén, prolaktin, progeszteron). MTF transzszexualitás esetén a prosztata nagyságának ultrahangos meghatározása, a mellek mirigyállományának és a májnak az ultrahangos vizsgálata célszerü. FTM transzszexualitás esetén a hormonkezelés megkezdése előtt a petefészkek és a mellek mirigyállományainak eltávolítása szükséges. A herék eltávolítása előtt megkezdett női hormonkezelés heredaganatot okozhat. A hereeltávolítás után a herezacskók sorvadnak, ugyanakkor ezekből alakítjuk ki a kis- és nagyajkakat. Az ideális időpontja a hereeltávolításnak a hüvelyképzéssel egy időben van, tehát nem célszerü e nagy műtét előtt megkezdeni a hormonkezelést. A hormonkezelések során 3-6 havonta endokrinológiai ellenőrzés javasolt, ami hormonvizsgálatok és egyéb laboratóriumi vizsgálatok végzését is magában foglalja. A plasztikai sebészek csak kis százaléka rendelkezik megfelelő tapasztalatokkal a transzszexuális nemátalakító mütétek területén. Ez a plasztikai sebészeten belül is igen speciális és szúk terület. Az SRS-sorozatok összetett és az átlagnál valamivel nagyobb kockázatú műtétekből állnak. A kockázatok maximális csökkentése érdekében az egymás utáni mútétek összehangolt, gondos megtervezése elengedhetetlen.

A fejlett országokhoz hasonlóan, a 2000-es évek elejéig Magyarországon is egyetlen központi, a mindenkori egészségbiztosítótól független testület, az ETT Igazságügyi Bizottsága engedélyezte a nemi átalakítás folyamatát. A bizottság 16. életévét betöltött magyar állampolgárról alakíthatott ki véleményt. A magyar állampolgár 18. életévének betöltése után kezdődhetett el a beavatkozási sorozat, amennyiben a vizsgált személynél a transzszexualizmus kórisméje az igazságügyi szakértők által egyhangúlag megállapítást nyert. A névváltoztatás az ivarmirigyek eltávolítása után történhetett meg. Ezen eljárásrend a későbbiekben úgy módosult, hogy a névváltoztatást kérelmező a betegségét igazoló igazságügyi pszichológus, igazságügyi pszichiáter, valamint a nőgyógyász vagy urológus, andrológus szakvéleményével együtt kérelmet nyújtott be az Országos Igazságügyi Orvostani Intézet vezetőjéhez személyes vizsgálat céljából. A transzszexualitás megállapítására az igazságügyi pszichiáter volt jogosult, aki az igazságügyi pszichológus véleményét is figyelembe véve igazolta a BNO-10 szerinti transzszexualizmus meglétét. Az Országos Igazságügyi Orvostani Intézet igazgatója által kijelölt személy a beteg személyes vizsgálatát követően engedélyezte a névváltoztatást, annak anyakönyvben való kijavítását. A kijelölt igazságügyi orvosszakértő feladata volt a beteg felvilágosítása, amelyről írásban nyilatkoztatnia kellett a beteget. Döntéséről értesítette a Belügyminisztérium Adatfeldolgozó, Nyilvántartó és Választási Hivatal Hatósági és Felügyeleti Főosztályát, ahol az engedély birto- kában a névváltoztatás anyakönyvi bejegyzése megtörtént. A névváltozás anyakönyvi bejegyzését követően, ha a kérelmező nemi átalakító mútéteket szeretett volna igénybe venni, akkor a belső nemi szervek és az emlő eltávolítása a megyei szülészet-nőgyógyászati, urológiai és sebészeti osztályokon, míg a külső nemi szervek átalakítása az arra kijelölt egészségügyi intézményekben történhetett meg (Szegedi Tudományegyetem, Urológiai Klinika; Fővárosi Önkormányzat Szent István Kórház, Plasztikai Sebészeti Osztály).

Az imént leírt gyakorlat sokat változott az évek folyamán, amelyet fentebb már részleteztem. Az eljárás leegyszerüsödött, amellyel, sajnos, a kockázatok is növekedtek. A nemi átalakítás egyik szakmai-etikai veszélye, ha nem megalapozott a diagnózis, és a páciens később megbánja, hogy mútétet kért és hogy annak alávetette magát.

Magyarországon jelenleg nem létezik törvényi szabályozás a kezelési folyamat menetére. Nincs kötelező protokoll, szakmai módszertani levél a betegek mútéti és hormonkezelés előtti kivizsgálására. Koordinátor nélkül a beteg maga menedzseli a folyamatot, gyakran maga dönti el az egyes beavatkozások sorrendjét, amely által a kezelési folyamat ad hoc jellegü, szakmailag jórészt kontrollálatlan. Az össze nem hangolt lépések miatt a beteg lényeges hátrányt szenved, a költségek pedig többszörösére emelkedhetnek. Az orvosok nem mindegyike ismeri a nemzetközi protokollokat. A szabályozatlanság miatt nincs az érintett szakterületek szakemberei számára a kezelésekre irányuló speciális képzés vagy továbbképzés. Az egyes beavatkozásokat végző szakembereknek nincs az egész folyamatra rálátásuk. A KIM engedélye után a beteg elkezdheti a kezelési folyamatot, és az esetek többségében többé nem látja a pszichiátert. A hormonkezelés előtt vagy azzal párhuzamosan sincs semmiféle pszichológiai felkészítés, mint ahogy utógondozás sincs [6].

\section{A finanszírozás kérdése}

A mütéti és hormonkezelés javallata között szerepel, hogy a betegségben szenvedők közt a komplex kezelés elmaradása esetén az átlagpopulációhoz képest csaknem ötszázszoros az öngyilkosságok aránya, míg átoperálások után ez az arány bár magasabb, mint az átlagpopulációban, de nagyságrendekkel csökken. Magyarországon az életbe lépett új törvényi szabályozás előtt a finanszírozás megoldatlansága miatt több év is eltelt, míg valamilyen terápiás kezelés elkezdődött. A betegek a mütétek folytatását anyagi okokból gyakran abbahagyták. Nemzetközi adatokból ugyanakkor ismeretes, hogy a valamely okból megszakadó mútéti sorozatok betegeinél az öngyilkosságok aránya nem csökken, hanem növekszik. Németországban a megfelelő protokollok teljesülése esetén az egészségbiztosító a '70-es évektől fedezi a költségeket, csakúgy, mint az Egyesült Államokban és csaknem mindegyik nyugat-európai országban.

Magyarországon annak ellenére nem támogatottak teljeskörüen az egészségbiztosító által a mütéti korrek- 
ciók, hogy a transzszexualizmus hivatalosan BNO-kóddal rendelkező betegség. A társadalombiztosító általában csak a mútéti költségek 10\%-át téríti, amelyről az 1997. évi LXXXIII. törvény a kötelező egészségbiztosítás ellátásairól 23. $\$$-a, valamint a 284/1997. (XII. 23.) Kormányrendelet 1. számú melléklete rendelkezik. Ez utóbbinak 6. pontja kimondja, hogy: „Az Ebtv. 23. S-ának k) pontja alapján a külsődleges nemi jellegek megváltoztatására irányuló beavatkozásért fizetendő részleges térítési díj mértéke annak az összegnek a 90\%-a, amely az ellátásért a külön jogszabályban foglaltak szerint az egészségbiztosító felé elszámolható.”

Méltányossági kérelem alapján lehetőség van - a kérelmező vagyoni helyzetétől függően - akár a teljes költségtérítés elengedésére is, amelyről az Országos Egészségbiztosítási Pénztár főigazgatójának 28/2008. (Eb. K. 10.) számú OEP-utasítása rendelkezik. A nemi átalakító mütétek normatív homogén betegségcsoportok alapú finanszírozás keretében kerülnek elszámolásra, azonban csak a csonkító mütétek végezhetők OEP-finanszírozásra, a rekonstrukciós mütétek nem. Az implantátumok, valamint a szükséges hormonszubsztitúció 50\%-os támogatottsággal rendelhető.

A név- és nemváltoztatás kérelmezéséhez szükséges szakvélemények tb-támogatással is megszerezhetők.

\section{Jogi szabályozás az Egyesült Királyságban}

Az Egyesült Királyságban a név- és nemváltoztatásnak több lehetséges módja is van. Az „eskü helyetti kijelentés” a név- és nemváltoztatás legegyszerúbb módja, amely során az illető közjegyző vagy bíróság előtt írásban kijelenti, hogy a jövőben nem kívánja régebbi nevét használni, hanem helyette egy új, megadott nevet kíván viselni [7]. Az „egyoldalú szerződés” általi névmódosítás szintén tanúk előtt írásban történik, amelyet a bíróság később hitelesít [8].

Az Egyesült Királyság törvényhozása 1975-ben, a Sex Discrimination Act-ben gondoskodott először a diszkrimináció kérdéséről, amely törvényt a transzszexuálisok védelme érdekében 1999-ben a The Sex Discrimination (Gender Reassignment) Regulations-ben kibővített. A The Criminal Justice Act 2003 kimondja, hogy a nemi identitás alapján keltett gyúlölet büncselekmény. 2004ben a The Gender Recognition Act biztosította, hogy a személy választott neme jogilag minden szinten el legyen ismerve. A törvény biztosítja, hogy amennyiben az illető bizonyos követelményeknek megfelel, úgy Nemi Elismerő Igazolást (Gender Recognition Certificate - GRC) kaphat, amely tanúsítja az illető választott nemét, biztosítja a választott nemével járó jogokat és kötelezettségeket. A GRC kiállításának feltétele, hogy az illető minimum két évig a választott nemnek megfelelően élt, és az új nemét véglegesnek tekinti, amelyet orvosilag is bizonyítani tud. A GRC kiállításának nem feltétele a hormonális vagy mütéti kezelés. A GRC birtokában az illető kérvényezheti a választott nemének megfelelő új anyakönyvi bizonyítvány kiállítását. A transzszexuális személynek nem kötelező felfednie, hogy birtokában van-e a GRC-nek. A The Gender Recognition Act-nek ugyanis pont az a célja, hogy a transzszexuális személynek ne kelljen felfednie külső megjelenése és polgári státusa eltérésének okát. A The Sex Discrimination (Gender Reassignment) Regulations törvényt 2010-ben a The Equality Act váltotta fel [9].

\section{A kezelési folyamat brit gyakorlata}

Az Egyesült Királyságban a nemváltoztatás folyamatát általában a háziorvos kezdeményezi, aki az állapot felismerése után pszichiáterhez vagy közvetlenül nemiidentitás-klinikára utalja a beteget. A pszichiáternek kulcsszerepe van a kezelés folyamatában. A teljes körü anamnézisfelvétel után megtörténik a diagnózisadás, amely után a pszichiáter felvilágosítást ad a betegnek a nemváltás folyamatáról, a sorstársakkal való kapcsolatfelvétel mikéntjéről és a helyi önkéntes szervezetek lehetséges támogató szerepéről. A pszichiáter ezután személyesen vagy a háziorvoson keresztül továbbutalja a beteget a nemiidentitás-klinikára. Angliában hat nemiidentitás-klinika múködik, amelyek területi lefedettséget biztosítanak az országnak. A legismertebb a West London Mental Health NHS Trust Gender Identity Clinic, ismertebb nevén Charing Cross Gender Identity Clinic, amely a legrégebbi ilyen szakszolgáltatást biztosító intézmény az Egyesült Királyságban, egyben jelenleg a világ legnagyobb nemiidentitás-központja. A kezelések egyik feltétele, hogy az illető betöltse a 16. életévét. Az egyedüli kezelés, amely fiatalkorban is elkezdhető, a pszichológiai terápia, ami egyedül a londoni Tavistock Klinikán érhető el. A nemiidentitás-klinikákon pszichiáter, pszichológus, sebész, endokrinológus, beszédterapeuta, szaknővér és tanácsadó egy csapatot alkot. A betegnek általában egy élettörténeti levelet kell írnia, amellyel a nemiidentitás-panel szakembereinek a döntését segíti. Miután a nemiidentitás-klinika elfogadta a referátumot, a betegnek legalább egy évig úgynevezett Real Life Test vagy Real Life Experience (RLT vagy RLE = Valódi Élet Teszt vagy Valódi Élet Tapasztalat) gyakorlatot kell folytatnia. Az RLT az a gyakorlat, miszerint a transzszexuálisnak a nemváltoztatási mútétek előtt meghatározott ideig a választott nemnek megfelelő módon kell élnie, hogy ezáltal kipróbálhassa a vágyott nemi identitását. Az RLT ideje alatt a tanácsadás a kedvezőtlen hatások csökkentésére szolgál. Beszédterápiás foglalkozások is kezdődnek. A másodlagos nemi jellegek megváltoztatásában is segítséget kap a beteg. A fizikális alapvizsgálatok elvégzésre kerülnek. Amennyiben ezek normális értéktartományon belül vannak, abban az esetben a hormonterápia megkezdődhet, vagyis az MTF transzszexuális az RLF ideje alatt kezdheti meg a feminizáló hormonkezelést. A vérnyomásmérés és vérképvizsgálat $4-5$ havonként kerül megismétlésre, amennyiben az értékek 
normáltartományban vannak. Az állami egészségügyi rendszeren belül a nemiidentitás-klinikák autonómiával rendelkeznek a nemváltoztatási beavatkozások terén, amely különösképpen igaz a mütéti beavatkozások területére. A klinikák saját feltételrendszerrel múködnek, amely rendszert sok kritika érte az elmúlt években. Bizonyos alapbeavatkozások minden klinikán elérhetőek, azonban a kozmetikai beavatkozások állami finanszírozása nem minden nemiidentitás-klinikán megoldott. Ez különösen igaz a mellplasztikai mútétekre. A mútéteket megelőző RLT gyakorlata minden klinika esetében kötelező, azonban ennek időtartama klinikánként eltérő. Ennek hossza általában három hónaptól két évig tarthat. Utógondozás történhet a klinikákon vagy a háziorvosi rendszerben. Amennyiben a transzszexuális személy elkezdte a kezelést az egyik nemiidentitás-klinikán, abban az esetben arra nincs módja, hogy az átalakulást másik klinikán folytassa. Az állami klinikák között nincs átjárásra lehetőség. A legtöbb transzszexuális személy az állami rendszert veszi igénybe, azonban a hosszú várólisták miatt egyesek a magánrendszert választják. Mindkét rendszernek vannak előnyei és hátrányai is. A két rendszer között lehetséges az átjárás [10, 11].

\section{Következtetések}

A nemi dysphoria kezelésének jól megalapozott és nemzetközileg elfogadott iránymutatása létezik. A transzszexualizmus klinikai menedzselése multidiszciplináris megközelítést igényel. Elengedhetetlen a kezelési folyamat koordinált menedzselése, és lényeges a beteg pszichiátriai-hormonális-mútéti komplex ellátása. Magyarország adottsága miatt célszerû lenne, ha az ellátás csak néhány régiós vagy egyetlen országos központban történne. Magyarországon a nemváltoztatásnak nincs összefüggő jogi kerete, nincs hivatalos szabályozása, illetve a kezelésnek kötelező eljárási menete. Az Egyesült Királyságban a kormány jogi keretet biztosított a nemi dysphoria kezeléséhez. A brit szakmai szervezetek a nemváltás folyamatának meghatározásával, annak átláthatóságával jó példát kínálnak e gyakorlat kialakításához. Magyarország gazdasági helyzete jelenleg, sajnos, nem teszi lehetővé az összes eszközös beavatkozás állami rendszeren belüli elérhetőségét, azonban az egészségügy átalakítása remélhetőleg többletterhek nélkül, a koordináció hatékonyabbá tételével enyhítheti e problémákat. A nemváltoztatás lehetőségeinek információja európai szinten hiányos [12]. Magyarországon a transzszexuális betegek elsősorban online felületeket használva sorstársaktól informálódnak (transvanilla.hu, pinkvanilla. hu). Sorstársakkal és szakemberekkel való személyes találkozásra hazánkban a Metamor Klub kínál lehetőséget, amely a Moravcsik Alapítvány szervezésében kerül megrendezésre. E példamutató kezdeményezéseken felül azonban állami beavatkozást igényelne a többféle médiumon keresztül elérhető, korrekt tájékoztatás biztosítása, valamint a társadalmi előítéletesség csökkentése.

Anyagi támogatás: A közlemény megírása anyagi támogatásban nem részesült.

A szerző a cikk végleges változatát elolvasta és jóváhagyta.

Érdekeltségek: A szerzőnek nincsenek érdekeltségei.

\section{Irodalom}

[1] BNO-10 Pocket Book with DSM-IV-TR definitions. [BNO-10 Zsebkönyv - DSM-IV-TR meghatározásokkal.] Animula Kiadó, Budapest, 2004. [Hungarian]

[2] American Psychiatric Association: Diagnostic and Statistical Manual of Mental Disorders. Fifth edition. APA, Arlington, VA, 2013.

[3] Green, R.: Sexual identity in 37 children raised by homosexual or transsexual parents. Am. J. Psychiatry, 1987, 135(6), 692-697.

[4] Bryant, K. E.: The politics of pathology and the making of gender identity disorder. A dissertation submitted in partial satisfaction of the requirements for the degree Doctor of Philosophy in Sociology. University of California, Santa Barbara, 2007.

[5] Kórász, K., Simon, L.: Diagnosis and differential diagnostic features of gender identity disorder. [A nemi identitászavar diagnosztikája és differenciáldiagnosztikai sajátosságai.] Psychiatr. Hung., 2008, 23(3), 196-205. [Hungarian]

[6] Solymár, B., Takács, J.: Wrong bodies and real selves: Transsexual people in the Hungarian social and health care system. Challenging identities. http://www.mirovni-institut.si/data/tinymce/ Publikacije/beyond\%20the\%20pink\%20curtain/09\%20-\%20 Bence\%20\&\%20Takacs.pdf

[7] Statutory declaration of change of name for adults. https://www. citizensadvice.org.uk/relationships/birth-certificates-and-changingyour-name/changing-your-name/Statutory-declaration-of-changeof-name-for-adults /

[8] Change your name by deed poll. https://www.gov.uk/changename-deed-poll/overview

[9] Gender Recognition Act 2004. http://www.legislation.gov.uk/ ukpga/2004/7/contents

[10] Wylie, K.: Good practice guidelines for the assessment and treatment of gender dysphoria. Royal College of Psychiatrists, London, 2006. www.pfc.org.uk/node/1430

[11] Tugnet, N., Goddard, J. C., Vickery, R. M., et al.: Current management of male-to-female gender identity disorder in the UK. Postgrad. Med. J., 2007, 83(984), 638-642.

[12] Whittle, S., Turner, L., Combs, R., et al.: Transgender EuroStudy: Legal survey and focus on the transgender experience of health care. ILGA Europe and TransGender Europe, 2008. http:// www.pfc.org.uk/pdf/eurostudy.pdf

(Kórász Krisztián dr., 68 The Heights, Charlton, London, SE7 8JH, United Kingdom e-mail: krisztian.korasz@oxleas.nhs.uk) 